\title{
The Influence of Summarizing Short Stories Towards Students' Narrative Writing Ability
}

\author{
Nur Amalia Solikhah ${ }^{1 凶}$, Ratna Arum Sari ${ }^{2}$ \\ ${ }^{1}$ Bina Sarana Informatika University, Purwokerto, Indonesia. \\ ${ }^{2}$ Universitas Sang Bumi Ruwa Jurai, Bandar Lampung, Indonesia. \\ 凶email: nur.nlk@bsi.ac.id
}

\section{Received:}

02 January 2022

\section{Revised:}

02 January 2022

\section{Accepted:}

06 January 2022

Published:

06 January 2022

\begin{abstract}
The objectives of the research are to know and describe the average score of students' narrative writing ability, and to know and describe whether there is an influence of Summarizing Short Stories towards students' narrative writing ability at SMP Negeri 8 Bandar Lampung in 2020/2021. Most of the students get difficulties in improving their language skills, especially in writing. Writing is a problem in expressing and developing ideas or thoughts into written form. Narrative text is one of kinds of text that should be learned by the students. To solve the problem above, the writer used the technique in teaching narrative writing that is Summarizing Short Stories. In this research, the writer chooses the title: "The Influence of Summarizing Short Stories towards Students' Narrative Writing Ability at the Second Semester of the Eighth Class at SMP Negeri 8 Bandar Lampung in 2020/2021". In this reseach, the writer analyzed the result by using t-test formula. The research was conducted at the eighth class of SMP Negeri 8 Bandar Lampung in 2020/2021. The students of VIIIa were as a sample that were taught by using Summarizing Short Stories. The result of the research showed that there was significant influence of using Summarizing Short Stories towards students' narrative writing ability. It is shown by the distribution list with $\mathrm{df}=\left(\mathrm{n}_{1}+\mathrm{n}_{2}-2\right)=(23+22-2)$ $=43$ obtained $t_{\text {table }} t_{0.95}$ or significance level of $5 \%$ and $t_{\text {table }} t_{0.99}$ or significance level of $1 \%$ was equal to 1.68 and 2.42 . there were lower than $t_{\text {count }}=3.84$ and the average score of students' narrative writing ability in experimental class $\left(\bar{x}_{1}=66.58\right)$ was higher than the students' score in control class $\left(\bar{x}_{2}: 56.14\right)$ at the second semester of the eighth class of SMP Negeri 8 Bandar Lampung in 2020/2021.
\end{abstract}

Keywords: Short Story; Narrative Text; Writing Abality; Summarizing Short Stories.

\section{INTRODUCTION}

Vocabulary is the basic element of language which someone needs in learning a language. People need to have various vocabularies to help them in all language skills. They are speaking, reading, listening and writing. Some students still find the difficulty in learning vocabulary due to various factors. Therefore, teacher as the 
facilitator needs to find good solution and strategy to make students interested and enjoy in learning vocabulary by offering various learning techniques. Teachers also should know how to design good material to improve students' achievement in the learning process.

Vocabulary is central to English language teaching. Murcia (2001) states that "Vocabulary learning is central to language acquistion, whether the language is first, second or foreign". Richard and Rodgers (2001) states that "Vocabulay is one of the most important aspects of foreign language learning".

Meanwhile, Hiebert and Kamil (2005) give their ideas about the definition of vocabulary. They stated that "Vocabulary is the knowledge of meanings of words." They also divided two types of vocabulary: active vocabulary that is used in speech and writing and passive vocabulary (receptive) that is known but not used by a person. People understand it when it is heard or read. Cameron (2001) states that "Vocabulary development is not only about learning words, but it is much more than that. Vocabulary development is also about learning formulaic phrases or chunks, finding words inside them, and learning even more about those words".

Keyword technique is one of technique or methods to enrich students' vocabulary mastery. It is a technique that can be used by teacher to improve students' memory in learning vocabulary. This technique requires students to think and find new words from a keyword given by teacher which uses visualization to organize and recall information. Based on the description above, the researcher interested in using strategy to teaching vocabulary used Keyword technique to improve the students' vocabulary mastery.

Foster (2009) stated that Keyword technique is a way of organizing information to make it easier to remember, typically by using codes, visual, imagery, or rhymes. According to Thornburry (2012), keyword or mnemonics are 'trick' to help retrieve items or rules that are stored in memory and that are not yet automatically retrievable. Hayes (2009) also states that "Keyword technique is a design formulation to support memory and students can encode better data by using the mnemonic order, so that is easier to remember later on". This technique has a formula on how students can improve and find new words from keyword concept that will be given by teacher.

According to Redjeki Agoestyowati (2010), in implementing keyword technique, there are seven steps of keyword technique as follows: (1) Start the class by asking the students this question: "Do you know KRISDAYANTI?" (The writer believes the students know her well). (2) Ask students to write down one word each about her on the board (It can be adjective, verbs, names of something, names of place, etc.). (3) It migh be like this :Beautiful, Rich, Sexy, Malang, Diva, Singer, Etc. (4) Then ask the students to make a presentation orally about Krisdayanti by using the words above, like this: Krisdayanti is not only a sexy woman but I think she is very beautiful. She is quite rich, too. She comes from Malang. She is a singer and she is one of the Indonesian's Divas. (5) Another students may have different opinion like this : Do you know Krisdayanti? She is a beautiful and sexy woman. This sexy woman is not from Jakarta but she is from Malang. This time, she often sings, so I can say that she is a singer and she is one 
of the Indonesian's Diva, because of that she is quite rich. (6) Ask the students to give their individual presentations in front of the class. (7) All students will have different sentence but a least they are using some similar words.

According to Amiryousefi and Ketabi (2011), elaborate the advantages of keyword technique as explained below.

a) Students are able to imagine the target words.

b) Students are able to understand the meaning of the target words and also use it well.

c) This technique is very effective in helping students to remember about things such as nouns, adjective and so on.

d) This technique will make students think more critically and creatively to find more words in learning vocabulary.

e) This technique has a good strategy for improving vocabulary mastery and can make students more interested in learning vocabulary.

Amiryousefi and Ketabi (2011) also state that keyword technique has some disadvantages as explained below:

a) The teaching learning activities take more time.

b) Teachers should be creative in enhancing students' imagination.

c) Students' understanding may be lower when teacher explains startegy about this technique.

d) This technique only focus on a few aspects and students might be less able to think further.

e) The class needs at least one dictionary for pairs of students.

Regarding to the advantages and the disadvantages of implementing the keyword technique in teaching vocabulary, it can be concluded that keyword technique is able to improve the students' vocabulary mastery and students' retention in memorizing. This technique also enables students to use the vocabulary properly. So, the aim of this research is to improve students' vocabulary mastery of the tenth grade through the use of Keyword technique.

\section{METHOD}

In this research, the writer used the experimental method in order to know the influence of summarizing short stories. The writer took two classes to be investigated. The first class wasused as experimental class and the second class wasused as control class. Variable is something being investigated to get the authentic data from the research. In this research consist of two variables, they are:

1. The independent of variable is summarizing short stories (X)

2. The dependent variable is students' narrative writing ability (Y)

The operational definition of variables is as follows:

1. Summarizing short stories in teaching writing means that the writer asks the students to summarize the stories given in teaching writing. 
2. The students' narrative writing ability is the students' ability in writing narrative text based on the generic structures of narrative text.

To get the data of students' narrative writing ability, the writer used writing test and the writer asked the students to make narrative text based on the topic provided, such as:

1. My Unforgettable experience.

2. My Embarrassing Moment.

3. My Love Story

In scoring students' narrative writing ability, the writer used the scoring system that is proposed by Heaton (1988:145) as follows:

Table 1. Scoring Students' Narrative Writing Ability

\begin{tabular}{|c|c|c|}
\hline No & & Score of Writing \\
\hline \multirow{4}{*}{ Content } & $30-27$ & Excellent to very good: knowledgeable-substantive-etc. \\
\hline & $26-22$ & Good to average: some knowledge of subject-adequate. \\
\hline & $21-17$ & Far to poor: limited knowledge of subject-little substantive-etc. \\
\hline & $16-13$ & Very poor: does not show knowledge of subject-non-substantive-etc. \\
\hline \multirow{4}{*}{ Organization } & $20-18$ & Excellent to very good: fluent expression-ideas clearly stated-etc. \\
\hline & $17-14$ & $\begin{array}{l}\text { Good to average: somewhat choppy-loosely organized but main ideas } \\
\text { stand out-etc. }\end{array}$ \\
\hline & $13-10$ & Fair to poor: non-fluent-ideas confused or disconnected-etc. \\
\hline & $9-7$ & Very poor: does not communicate-no organization-etc. \\
\hline \multirow{4}{*}{ Vocabulary } & $20-18$ & $\begin{array}{l}\text { Excellent to very good: sophisticated range-effective word/idiom choice } \\
\text { and usage-etc. }\end{array}$ \\
\hline & $17-14$ & $\begin{array}{l}\text { Good to average: adequate range-occasional errors of word/idiom form, } \\
\text { choice, usage but meaning not obscured. }\end{array}$ \\
\hline & $13-10$ & $\begin{array}{l}\text { Fair to poor: limited range-frequent errors of word/idiom form, choice } \\
\text { usage-etc. }\end{array}$ \\
\hline & $9-7$ & Very poor: essentially translation-little knowledge of English vocabulary. \\
\hline \multirow{4}{*}{ Language use } & $25-22$ & Excellent to very good: effective complex construction-etc. \\
\hline & $21-19$ & Good to average: effective but simple constructions-etc. \\
\hline & $17-11$ & Fair to poor: problems in simple/complex construction-etc. \\
\hline & $10-5$ & Very poor: essentially translation-little knowledge of English vocabulary. \\
\hline \multirow{4}{*}{ Mechanics } & 5 & Excellent to very good: demonstrates mastery of convention-etc. \\
\hline & 4 & $\begin{array}{l}\text { Good to average: occasional errors of spelling, punctuation, } \\
\text { capitalization etc. }\end{array}$ \\
\hline & 3 & Fair to poor: frequent errors of spelling, punctuation, capitalization-etc. \\
\hline & 2 & $\begin{array}{l}\text { Very poor: no mastery of conventions-dominated by errors of spelling, } \\
\text { punctuation, and capitalization, paragraphing-etc. }\end{array}$ \\
\hline
\end{tabular}

The supporting technique : observation, documentation, and library study. The population of this research is the students of the second semester of the eighthclass of SMP Negeri 8 Bandar Lampung in 2020/2021. There are 253 Students in eleven parallel classes. 
Table 2. The Population of the Eighth Class of SMP Negeri 8 Bandar Lampung

\begin{tabular}{|c|c|c|c|c|}
\hline \multirow{2}{*}{ No. } & \multirow{2}{*}{ Class } & \multicolumn{2}{|c|}{ Gender } & \multirow{2}{*}{ Total } \\
\cline { 3 - 4 } & & Male & Female & 23 \\
\hline 1 & VIII A & 10 & 12 & 23 \\
2 & VIII B & 11 & 12 & 23 \\
3 & VIII C & 10 & 13 & 22 \\
4 & VIII D & 10 & 13 & 25 \\
5 & VIII E & 11 & 14 & 23 \\
6 & VIII F & 13 & 10 & 23 \\
7 & VIII G & 11 & 12 & 23 \\
8 & VIII H & 13 & 10 & 22 \\
9 & VIII I & 10 & 12 & 23 \\
10 & VIII J & 13 & 10 & 23 \\
11 & VIII K & 13 & 10 & 253 \\
\hline \multicolumn{2}{r}{ Total } \\
\hline
\end{tabular}

Arikunto (1986) states "The subject less than 100, it should be taken of all but if the subject more than 100 , it should be taken $10-15 \%$ or $20-25 \%$ more." Based on the statement above, the writer took two classes as the sample of the research. They are experimental class and control class. In this research, the writertook the samples by using cluster random sampling, because the population is homogenous.

The instrument of research : the validity of the test, and the readibility of the test. In analyzing the data, the writer used quantitative analysis in order to know the influence of summarizing short stories towards students' narrative writing ability. The formula that was used in this research is t-test. Before using the t-test the writer determined the average Rate $(\bar{x})$ and Variant $\left(S^{2}\right)$.

\section{FINDINGS AND DISCUSSION}

\section{The Result of Experimental Class}

The result of students' narrative writing ability in the experimental class can be seen in the following table:

Table 3. The result of the experimental class

\begin{tabular}{cc}
\hline No & Score of Writing \\
\hline 1 & 60 \\
2 & 70 \\
3 & 60 \\
4 & 65 \\
5 & 73 \\
6 & 80 \\
7 & 50 \\
8 & 70 \\
9 & 65 \\
10 & 50 \\
11 & 75 \\
\hline
\end{tabular}




\begin{tabular}{ll}
\hline 12 & 73 \\
13 & 68 \\
14 & 60 \\
15 & 60 \\
16 & 58 \\
17 & 80 \\
18 & 70 \\
19 & 50 \\
20 & 83 \\
21 & 75 \\
22 & 73 \\
23 & 60 \\
\hline
\end{tabular}

The Normality of the Result Test in Experimental Class

Base on the table above, the writer got the highest score was 83 and lowest score was 50 from $(\mathrm{n})=23$

Span R = the highest score - the lowest score

$$
\begin{aligned}
& =83-50 \\
& =33
\end{aligned}
$$

Total number of interval class $(K)=1+3.3 \log \mathrm{n}$

$$
\begin{aligned}
& =1+3.3 \log 23 \\
& =1+3.3(1.36) \\
& =1+4.488 \\
& =5.488 \\
& =5.5
\end{aligned}
$$

Length of interval class $(\mathrm{P})$

$$
\begin{aligned}
& =\frac{R}{K} \\
& =\frac{33}{5.5} \\
& =6
\end{aligned}
$$

Then the result above was included into table of distribution frequency as follows:

Table 4. The Distribution of the Test Result of Experimental Class

\begin{tabular}{cccccc}
\hline Score & $\boldsymbol{f}_{i}$ & $\chi_{i}$ & $\chi_{\mathbf{1}}^{\mathbf{2}}$ & $f_{i} \chi_{1}$ & $f_{i} \chi_{\mathbf{1}}^{\mathbf{2}}$ \\
\hline $\mathbf{5 0}-\mathbf{5 5}$ & 3 & 52.5 & 2756.25 & 157.5 & 8268.75 \\
$\mathbf{5 6}-\mathbf{6 1}$ & 6 & 58.5 & 3422.25 & 351 & 20533.5 \\
$\mathbf{6 2}-\mathbf{6 7}$ & 2 & 64.5 & 4160.25 & 129 & 8320.5 \\
$\mathbf{6 8}-\mathbf{7 3}$ & 7 & 70.5 & 4970.25 & 493.5 & 34791.75 \\
$\mathbf{7 4}-\mathbf{7 9}$ & 2 & 76.5 & 5852.25 & 153 & 11704.5 \\
$\mathbf{8 0}-\mathbf{8 5}$ & 3 & 82.5 & 6806.25 & 247.5 & 20418.75 \\
\hline Total & $\mathbf{2 3}$ & $\mathbf{4 0 5}$ & $\mathbf{2 7 9 6 7 . 5}$ & $\mathbf{1 5 3 1 . 5}$ & $\mathbf{1 0 4 0 3 7 . 7 5}$ \\
\hline \multicolumn{5}{c}{ Source: the data analysis }
\end{tabular}

From the table above, the writer obtained:

$N_{1} \quad=23$

$f_{1} \chi_{1}=1531.5$ 
$f_{1} \chi_{1}^{2}=104037.75$

So, it can be used to search the average and standard deviation as follows:

$$
\begin{gathered}
\bar{x}=\frac{\Sigma f 1 \chi 1}{f 1} \\
\bar{x}=\frac{1531.5}{23} \\
=66.58
\end{gathered}
$$

Standard deviation:

$$
\begin{aligned}
S_{1}^{2}=\frac{n\left(\sum f_{1} x_{1}^{2}\right)-\left(\sum f_{1} x_{1}\right)^{2}}{n 1(n 1-1)} \\
S_{1}^{2}=\frac{23(104037.75)-(1531.5)^{2}}{23(23-1)} \\
S_{1}^{2}=\frac{2392868.25-2345492.25}{23(22)} \\
S_{1}^{2}=\frac{47376}{23(22)} \\
S_{1}^{2}=\frac{47376}{506} \\
S_{1}^{2}=93.63 \\
S_{1}=\sqrt{93.63} \\
S_{1}=9.68
\end{aligned}
$$

\begin{tabular}{|c|c|c|c|c|c|}
\hline $\mathrm{X}$ & $\mathrm{Z}$ & $\mathrm{Z}_{1}$ & $\mathrm{~L}$ & $\overline{\mathrm{Ei}}$ & $\mathrm{Oi}$ \\
\hline \multirow[t]{2}{*}{49.5} & -1.76 & 0.4608 & & & \\
\hline & & & 0.0879 & 2.02 & 3 \\
\hline \multirow[t]{2}{*}{55.5} & -1.14 & 0.3729 & & & \\
\hline & & & 0.1744 & 4.01 & 6 \\
\hline \multirow[t]{2}{*}{61.5} & -0.52 & 0.1985 & & & \\
\hline & & & 0.2383 & 5.48 & 2 \\
\hline 67.5 & 0.10 & 0.0398 & & & \\
\hline
\end{tabular}

The next step is determining the expected frequency and observed frequency (Oi):

1. Deliminated the boundary of the class $(\mathrm{X})$ by subtracting the lowest score in the class 0.5 calculating $\mathrm{Z}$ for the boundary of the class with the formula

$$
\mathrm{Z}=\frac{x-\bar{x}}{S}
$$

2. Calculating with of international class by looking $Z_{1}$, value list.

3. Calculating expecting frequency (Ei) by multiplying the wide of every interval with the total of the data: $\mathrm{Ei}=\mathrm{L} . \mathrm{n}$

By using the step of the formula above, the writer got the result as follows:

Table 5. The List of the Distribution of Expected Frequency and Observed Frequency 


\begin{tabular}{llllll}
\hline 73.5 & 0.71 & 0.2612 & 0.2214 & 5.09 & 7 \\
79.5 & 1.33 & 0.4082 & 0,1470 & 3.38 & 2 \\
85.5 & 1.95 & 0.4744 & 0.0662 & 1.52 & 3 \\
\hline
\end{tabular}

$$
\begin{aligned}
X^{2} \text { ratio }= & \sum_{i=1}^{n} \frac{\left(O_{i}-E_{i}\right)^{2}}{E_{i}} \\
X^{2} \quad \text { ratio }= & \frac{(3-2.02)^{2}}{2.02}+\frac{(6-4.01)^{2}}{4.01}+\frac{(2-5.48)^{2}}{5.48}+\frac{(7-5.09)^{2}}{5.09}+\frac{(2-3.38)^{2}}{3.38} \\
& \quad+\frac{(3-1.52)^{2}}{1.52} \\
X^{2} \quad \text { ratio }= & \frac{(1.9044)}{2.02}+\frac{(3.9601)}{4.01}+\frac{(12.1104)}{5.48}+\frac{(3.6481)}{5.09}+\frac{(1.9044)}{3.38}+\frac{(2.1904)}{1.52} \\
X^{2} \quad \text { ratio }= & 0.94+0.99+2.21+0.72+0.56+1.44 \\
X^{2} \text { ratio }= & 6.86
\end{aligned}
$$

Test criterion :

Reject Ho if : $X^{2} \quad$ ratio $\geq X^{2} \quad$ table $(1-\alpha)(k-3)$

For the significant level of $5 \%(\alpha=0.05)$ obtained:

$X^{2} \quad$ table $=X^{2}(1-0.05)(6-3)$

$$
\begin{aligned}
& =X^{2}(0.95)(3) \\
& =7.81
\end{aligned}
$$

For the significant level of $1 \%(\alpha=0.01)$ obtained:

$$
\begin{aligned}
& X^{2} \quad \text { table }=X^{2}(1-0.01)(6-3) \\
& =X^{2}(0.99)(3) \\
& =11.3
\end{aligned}
$$

From the calculating above, it was good at significant level of 0.05 and also 0.01 the reality:

$X^{2}$ ratio $<X^{2}$ table

So, the hypothesis is accepted, it means the sample comes from the population that has normal distribution.

\section{The Result of Control Class}

The result of students' narrative writing ability in control class can be seen in the following table:

Table 6. The Result of Control Class Test

\begin{tabular}{cc}
\hline No & Score of Writing \\
\hline 1 & 70 \\
2 & 50 \\
\hline
\end{tabular}




\begin{tabular}{lll}
\hline 3 & 67 \\
4 & 55 \\
5 & 50 \\
6 & 53 \\
7 & 70 \\
8 & 50 \\
9 & 70 \\
10 & 45 \\
11 & 43 \\
12 & 50 \\
13 & 67 \\
14 & 45 \\
15 & 60 \\
16 & 60 \\
17 & 67 \\
18 & 55 \\
19 & 48 \\
20 & 53 \\
21 & 60 \\
22 & 45 \\
\hline
\end{tabular}

\section{The Normality Data of Control Class}

Base on the table above, the writer got the highes score was 70 and the lowest score was 43 from $(n)=22$

Span R = the highest score - the lowest score

$$
\begin{aligned}
& =70-43 \\
& =27
\end{aligned}
$$

Total number of interval class $(\mathrm{K})=1+3.3 \log \mathrm{n}$

$$
\begin{aligned}
& =1+3.3 \log 22 \\
& =1+3.3(1.34)
\end{aligned}
$$$$
=1+4.422
$$$$
=5.422
$$

Length of interval class $(\mathrm{P}) \quad=\frac{R}{K}$

\begin{tabular}{|c|c|c|c|c|c|}
\hline Score & $\overline{f_{2}}$ & $x_{2}$ & $\chi_{2}^{2}$ & $f_{2} \chi_{2}$ & $f_{2} \chi_{2}^{2}$ \\
\hline $43-47$ & 4 & 45 & 2025 & 180 & 8100 \\
\hline $48-52$ & 5 & 50 & 2500 & 250 & 12500 \\
\hline $53-57$ & 4 & 55 & 3025 & 220 & 12100 \\
\hline $58-62$ & 3 & 60 & 3600 & 180 & 10800 \\
\hline $63-67$ & 3 & 65 & 4225 & 195 & 12675 \\
\hline
\end{tabular}

$$
\begin{aligned}
& =5.4 \\
& =\frac{R}{K} \\
& =\frac{27}{5.4} \\
& =5
\end{aligned}
$$

Then the result above was included into table of distribution frequency as follows:

Table 7 The Distribution of the Test Result of Control Class 


\begin{tabular}{llllll}
\hline $\mathbf{6 8}-\mathbf{7 2}$ & 3 & 70 & 4900 & 210 & 14700 \\
\hline Total & $\mathbf{2 2}$ & $\mathbf{3 4 5}$ & $\mathbf{2 0 2 7 5}$ & $\mathbf{1 2 3 5}$ & $\mathbf{7 0 8 7 5}$ \\
\hline
\end{tabular}

Source: the data analysis

From the table above, the writer obtained:

$N_{2} \quad=22$

$f_{2} \chi_{2}=1235$

$f_{2} \chi_{2}^{2}=70875$

So, it can be used to search the average and standard deviation as follows:

$$
\begin{gathered}
\bar{x}=\frac{\Sigma \mathrm{f} 2 \chi 2}{\mathrm{f} 2} \\
\bar{x}=\frac{1235}{22} \\
=56.14
\end{gathered}
$$

Standard deviation:

$S_{2}^{2}=\frac{n\left(\Sigma_{2} x_{2}^{2}\right)-\left(\Sigma_{2} x_{2}\right)^{2}}{n 2(n 2-1)}$

$S_{2}^{2}=\frac{22(70875)-(1235)^{2}}{22(22-1)}$

$S_{2}^{2}=\frac{1559250-1525225}{22(21)}$

$S_{2}^{2}=\frac{34025}{22(21)}$

$S_{2}^{2}=\frac{34025}{462}$

$S_{2}^{2}=73.65$

$S_{2}=\sqrt{73.65}$

$$
S_{2}=8.60
$$

The next step is determining the expected frequency and observed frequency (Oi):

1. Delimited the boundary of the class $(\mathrm{X})$ by subtracting the lowest score in the class by 0.5 calculating $\mathrm{Z}$ for the boundary of the class with the formula

$\mathrm{Z}=\frac{x-\bar{x}}{S}$

2. Calculating with of international class by looking $Z_{1}$, value list.

3. Calculating expecting frequency (Ei) by multiplying the wide of every interval with the total of the data : $\mathrm{Ei}=\mathrm{L} . \mathrm{n}$

By using the step of the formula above, the writer got the result as follows:

Table 8. The List of the Distribution of Expected Frequency and Observed Frequency

\begin{tabular}{cccccc}
\hline $\mathbf{X}$ & $\mathbf{Z}$ & $\mathbf{Z}_{1}$ & $\mathbf{L}$ & $\mathbf{E i}$ & $\mathbf{O i}$ \\
\hline 42.5 & -1.59 & 0.4441 & & & \\
47.5 & -1.00 & 0.3413 & 0.1028 & 2.26 & 4 \\
\hline
\end{tabular}




\begin{tabular}{llllll}
\hline 52.5 & -0.42 & 0.1628 & 0.1785 & 3.92 & 5 \\
57.5 & 0.16 & 0.0636 & 0.2264 & 4.98 & 4 \\
62.5 & 0.74 & 0.2703 & 0.2067 & 4.55 & 3 \\
67.5 & 1.32 & 0.4066 & 0.1363 & 2.10 & 3 \\
72.5 & 1.90 & 0.4713 & 0.0647 & 1.42 & 3 \\
\hline
\end{tabular}

$$
\begin{aligned}
X^{2} \text { ratio }= & \sum_{i=1}^{n} \frac{\left(O_{i}-E_{i}\right)^{2}}{E_{i}} \\
X^{2} \quad \text { ratio }= & \frac{(4-2.26)^{2}}{2.26}+\frac{(5-3.92)^{2}}{3.92}+\frac{(4-4.98)^{2}}{4.98}+\frac{(3-4.55)^{2}}{4.55}+\frac{(3-2.10)^{2}}{2.10} \\
& \quad+\frac{(3-1.42)^{2}}{1.42} \\
X^{2} \quad \text { ratio }= & \frac{(3.0276)}{2.26}+\frac{(1.1664)}{3.92}+\frac{(0.9604)}{4.98}+\frac{(2.4025)}{4.55}+\frac{(0.8100)}{2.10}+\frac{(2.4964)}{1.42} \\
X^{2} \quad \text { ratio }= & 1.34+0.30+0.19+0.53+0.39+1.76 \\
X^{2} \quad \text { ratio }= & 4.51
\end{aligned}
$$

Test criterion :

Rejected Ho if : $X^{2} \quad$ ratio $\geq X^{2} \quad \operatorname{table}_{(1-\alpha)(k-3)}$

For the significant level of $5 \%(\alpha=0.05)$ obtained:

$$
\begin{aligned}
X^{2} \quad \text { table } & =\mathrm{X}^{2}(1-0.05)(6-3) \\
& =\mathrm{X}^{2}(0.95)(3) \\
& =7.81
\end{aligned}
$$

For the significant level of $1 \%(\alpha=0.01)$ obtained:

$$
\begin{aligned}
& X^{2} \quad \text { table }=X^{2}(1-0.01)(6-3) \\
& =X^{2}(0.99)(3) \\
& =11.3
\end{aligned}
$$

From the calculating above, it was good at significant level of 0.05 and also 0.01 the reality:

$X^{2}$ ratio $<X^{2}$ table

So, the hypothesis is accepted, it means the sample comes from the population that has normal distribution.

\section{The Homogeneity Test of Variance}

The next step, after knowing that the data has normal distribution, so the writer did the examination of homogeneity variance from both samples by the hypothesis formula below:

Ho: $\sigma_{1}^{2}=\sigma_{2}^{2}$ (both samples have the equality of variant) 
Ha: $\sigma_{1}^{2} \neq \sigma_{2}^{2} \quad$ (both samples have the different of variant)

Statistic formula that will use is:

$\mathrm{F}=\frac{S^{2} \text { Highestvariants }}{S^{2} \text { Smallestvariants }}$

From the calculating above gained:

1. The highest variance that is the value of standard deviation from experimental class $\left(S_{1}^{2}=93.63\right)$

2. The lowest variance that is the value of standard deviation from control class $\left(S_{2}^{2}\right.$ $=73.65$ )

The next step, the data are included into the formula:

$\mathrm{F}=\frac{S^{2} \text { Highestvariants }}{S^{2} \text { Smallestvariants }}$

$\mathrm{F}=\frac{93.63}{73.65}$

$\mathrm{F}=1.27$

The test criterion:

Rejected the $H o$ if $F_{\text {ratio }} \geq F_{\text {table }} \frac{1}{2} a\left(V_{1} \cdot V_{2}\right)$ with $\mathrm{V}_{1}=\mathrm{n}_{1}-1 \mathrm{~V}_{2}=\mathrm{n}_{2}-1$

And also it uses the real level 0.05 and 0.01

For $\alpha=0.05$ obtained from $\mathrm{F}_{\text {table }}=\mathrm{F} \frac{1}{2} \cdot 0.05(22.21)$

$$
=11.55
$$

For $\alpha=0.01$ obtained from $\mathrm{F}_{\text {table }}=\mathrm{F} \frac{1}{2} \cdot 0.01(22.21)$

$$
=2.31
$$

From the calculating above that at level 0.05 and 0.01 were obtained $\mathrm{F}_{\text {ratio }}<\mathrm{F}_{\text {table, }}$, so that Ho is accepted and it means that the sample has homogeneous variance.

\section{The Hypothesis Test}

In this research, the writer used $t_{\text {test }}$ formula as follows:

$$
t_{\text {test }}=\frac{\bar{x}_{1}-\bar{x}_{2}}{\sqrt[s]{\frac{1}{n_{1}}+\frac{1}{n_{2}}}}
$$

With

$S^{2}=\frac{\left(n_{1}-1\right) S_{1}^{2}\left(n_{2}-1\right) S_{2}^{2}}{n_{1}+n_{2}-2}$

Notes:

$n_{1}: 23$

$n_{2}: 22$

$\bar{x}_{1}: 66.58$

$\bar{x}_{2}: 56.14$

$s_{1}^{2}: 93.63$

$s_{2}^{2}: 73.65$

$S^{2}=\frac{(23-1) 93.63+(22-1) 73.65}{23+22-2}$ 


$$
\begin{aligned}
& S^{2}=\frac{(22) 93.63+(21) 73.65}{43} \\
& S^{2}=\frac{2059.86+1546.65}{43} \\
& S^{2}=\frac{3606.51}{43} \\
& S^{2}=83.87 \\
& S=\sqrt{83.87} \\
& S=9.16
\end{aligned}
$$

The next step, the data that has been got is included into $t_{\text {test }}$ formula:

$$
\begin{aligned}
t_{\text {test }} & =\frac{\bar{x}_{1}-\bar{x}_{2}}{\sqrt[s]{\frac{1}{n_{1}}+\frac{1}{n_{2}}}} \\
t_{\text {test }} & =\frac{66.58-56.14}{\sqrt[9.16]{\frac{1}{23}+\frac{1}{22}}}
\end{aligned}
$$

$$
\begin{aligned}
t_{\text {test }} & =\frac{10.44}{\sqrt[9.16]{0.043+0.045}} \\
t_{\text {test }} & =\frac{10.44}{\sqrt[9.16]{0.088}}
\end{aligned}
$$$$
t_{\text {test }}=\frac{10.44}{2.72}
$$$$
t_{\text {test }}=3.84
$$

\section{Discussion}

Based on the result research, the writer would like to inform that using summarizing short stories is one of a good technique to motivate students in learning English especially in learning writing. It because there are 4 students who got low score in experimental class, and there are 13 students who got low score in control class.

However in this research the writer also found some obstacles in applying Summarizing Short Stories in learning writing. The writer found that there are some problem when applying this technique. For example, the students were lazy in reading the whole story of short stories. Beside that, some students got difficulties in understanding the story. They took long time to find the meaning of words in dictionary. It because they have lack of vocabularyand also they don't master in grammar. To solve those problem, the writer gave motivation for students by giving the interesting short stories, so the students felt entertain when they read and summarized the story. For the students who still got low score, they need to be given intensive training in learning English especially in learning narrative text witing.

Based on the data analysis of the data and testing of hypothesis the writer got the result that $\mathrm{Ho}$ is rejected and $\mathrm{Ha}$ is accepted. It showed by the average score of experimental class is (66.58) and the average score of control class is (56.14). It also showed byt $t_{\text {count }}$ that was higher than $t_{\text {table }}$ with significant level 1\% and 5\% (3.84 > 2.70> 
2.02). So, it means that there is a significant influence of summarizing short stories towards students narrative writing ability.

It is clear that Summarizing Short Stories can help students' in writing. It means that Summarizing Short Stories do not only practice students' narrative writing ability but also it improves students' knowledge in writing. In this case the writer assumes that Summarizing Short Stories is a good technique for teaching writing, so this technique is better if the teacher uses it for teaching writing, especially in teaching narrative writing.

\section{CONCLUSION}

The writer tried to wrap the conclusion of the research as follows:

1. The average score of students' narrative text writing ability which is taught through summarizing short stories was higher than which is taught through lecturing.

2. There is a significance influence of summarizing short stories towards students' narrative writing ability at the second semester of the eighth class of SMP Negeri 8 Bandar Lampung in 2020/2021.

\section{REFERENCES}

Abdollahzadeh, E., \& Baniasad, S. (2010). Ideologies in the imported English textbooks: EFL learners and teachers' awareness and attitude. Journal of English Language Teaching and Research, 53(217), 1-17.

Anderson, Mark. and Anderson, Kathy. (1997). Text Types in English 2. Australia: MacMillan Education Australia.

Alderson, J. C. (2000). Assessing Reading. Assessing Reading. https://doi.org/10.1017/cbo9780511732935

Arikunto, Suharsimi. (1986). Dasar-dasarEvaluasiPendidikan. Jakarta: BinaAksara.

Brown, H.Douglas. (2007). Principles of Language Learning and Teaching, Third Edition. United States of America: Prentice Hall Regents.

(2001). Teaching by Principles: An Interactive Approach to Language Pedagogy Second Edition. Longman Inc.

Byrne, Donn. (1988). Teaching Writing Skills. England: Longman Group UK Limited.

Cameron, Lynne. (2001). Teaching Language to Young Learners. United Kingdom Cambridge: University Press.

Crimmon, Mc. James M. (1984). Writing With a Purpose. U.S.A: Houghton Mifflin Company.

Finocchiaro, Mary and Bonomo. (1984). English as Second Language from Theory and Practice. New York: Regent Publisher Company Division of Simon and Schuster, Inc.

Freedman, Leora. (2012). English Language Learning, Arts \& Science. Available at: http://www.writing.utoronto.ca/advice/reading-and-researching/summarize

H. William, Dubay. (2004). The Principles of Readability. Available at: http://impactinformation.com/impactinfo/readability02.pdf

Harmer, Jeremy. (2004). How to Teach Writing. England: Pearson Education Limited. 
Heaton, John.B. (1988). Writing English Language Test. London and New York: Longman.

Hughes, Arthur. (1989). Testing for Language Teacher. New York: Cambridge University Press.

Linderman, Erika. (1982). What is Writing: A Rhetorical for Writing Teachers. The University of Chicago Press.

Lister, M., Dovey, J., Giddings, S., Grant, I., \& Kelly, K. (2009). New media: a critical introduction. https://doi.org/10.1177/026858090702200234

Oshima, Alice and Hogue, Ann. (1991). Writing Academic English, Third Edition. Addison Wesley Longman.

Richards, C. Jack and Rodgers, S. Theodore. (2001). Approaches and Methods in Language Teaching. United States America: Cambridge University Press.

Sudjana. (2005). MetodaStatistika. Bandung: Tarsito. 